\title{
A Study on the Improvement of Teachers' Ability from the Perspective of Automobile Specialty
}

\author{
Yang Guangming ${ }^{1}$, Gao Yan $^{2}$ \\ ${ }^{1}$ Automobile Application Technology Department, Career Technical College of Hefei, Chaohu, China \\ ${ }^{2}$ Teachers' Ability Development Center for Vocational Colleges in Hefei, Heifei, China
}

\section{Email address:}

565954139@qq.com (Yang Guangming),280082664@qq.com (Gao Yan)

\section{To cite this article:}

Yang Guangming, Gao Yan. A Study on the Improvement of Teachers' Ability from the Perspective of Automobile Specialty. Science Innovation. Vol. 5, No. 4, 2017, pp. 227-230. doi: 10.11648/j.si.20170504.16

Received: April 1, 2017; Accepted: April 30, 2017; Published: May 11, 2017

\begin{abstract}
Through the teacher into the enterprise practice problems, needs and teaching activities in the knowledge, make enterprise and school training from professional master training module, v0ehicle master, let the teachers to improve themselves, develop their own school, making training plan according to the needs of teachers, enterprises develop training program, with the help of the Internet, the establishment of the mechanism, standardize enterprise and school teachers practice standards, and strive to create better teachers, cultivate talents, eventually in the promotion of other specialties.
\end{abstract}

Keywords: Practical Activities, Problems, Current Situation Analysis, Concrete Measures

\section{从汽车专业视角谈企业实践提升教师能力的研究}

杨光明 ${ }^{1}$, 高艳 ${ }^{2}$

${ }^{1}$ 汽车应用技术系, 合肥职业技术学院, 巢湖, 中国

合肥学院合肥职业院校教师能力发展中心, 合肥, 中国

邮箱

565954139@qq. com（杨光明），280082664@qq.com（高艳）

摘要: 通过教师进企业实践活动存在的问题, 以及教学活动中所需要的知识, 提出让企业与学校从专业模块大师培训, 车型大师培训方式, 让教师提升自己, 拓展自己, 学校根据教师需求制定培训计划, 企业制定培训方案, 借助互联网+ 完成, 建立机制、规范企业和学校教师的实践活动准则, 着力打造双师, 更好培养技能型人才, 最终在其他专业推广。

关键词: 实践活动, 存在问题, 现状分析, 具体措施

\section{1. 概述}

组织职业院校教师去企业实践活动, 是培养提升专业 课教师教学能力的重要手段, 让教学课堂、工作岗位零距 离对接, 老师像学生一样, 以企业行为为导向学习, 以企 业标准, 行业标准, 国家标准为学习任务, 提升自身教学 能力 [1]。教师教学水平的高低, 直接决定为社会输送的
技能型人才质量, 提升教师队伍的专业素养, 打造一支符 合现代职教体系的师资队伍, 有着重要的意义 [2]。拟通 过汽车专业教育进行分析。

随着汽车工业的发展, 汽车维修技术含量提升, 高技 能型人才需求骤增。提升教师教学能力, 打造出 “双师型” 
队伍, 积极拓展学生思维, 提高学生分析问题, 解决问题 能力。教师能力强可以根据企业工作场景, 突出实现专业 课教学和企业生产对接。

德国是在世界上教育搞得最好的国家，对教师的准入 制度最严，老师必须要取得文凭，要有几年实践，通过考 核取得证书。我国现在 “双师型” 教师培育, 可以联合相 关的生产企业, 让企业参与现代教育体系建设。接纳职业 院校教师参与企业生产、经营、管理全过程。学习实际操 作技能、工艺过程。职业岗位能力对人才知识和能力需求。 掌握企业生产、服务、管理的理念、技术和技能, 采集专 业教学、学生实习实训所需的各种技术资料等 [3]。

\section{2. 教师到企业实践活动中的存在问题}

\section{1. 制度不完善, 企业参与意识不强}

教师进企业实践活动, 缺少相应的约束与激励机制, 没有针对教师量化考核标准, 进行质量监控。缺少相关的 法律条文, 来约束双方, 在德国、奥地利、芬兰等教育发 达国家，都有一套完整的法律体系 [4]。

教育部门没有能力约束企业, 没有政策保证, 企业必 须接受教师实践活动, 企业没有配套政策和实施措施, 企 业的主要任务是生产, 抵触培养教师, 参与意愿不足 [5]。

\section{2. 缺少财政支持, 经费保障渠道不畅通}

专业教师进入汽车企业, 需要配备专业技术力量来授 课和管理, 涉及汽车零部件损坏, 耗材使用, 提供教师实 习装备和防护用品等。影响企业效益, 补偿渠道不畅通, 缺少长效机制。通过对政府开支报表显示对企业这块虽然 有专项资金但落实到位效果比较差。在德国的企业不但要 承担教师的沟通与学习任务, 学生的双元制学习也要付给 工资的。

\section{3. 缺少考核机制，合作双方互相迁就问题}

通过省内外157家职业院校到67家企业实践活动的调 研, 问卷调查, 主要问题: 实践活动中, 没有考核机制, 没有硬性指标, “双师型” 教师紧缺, 教师进步欲望不强。 实践培训效果不好; 企业担心技术外泄、影响生产, 担心 教师安全问题; 双方不能融合问题, 双方要求不严。教师 因为企业态度、实践时间、学习待遇等情绪影响, 企业因 为教师不是员工, 技术有所保留, 要求不高, 造成双方相 互迁就。

\section{4. 企业缺少培训经验, 难以完成培训效果}

企业没有专门的培训机构, 不会制定培训计划, 培训 经验不足; 教师进入企业, 培训随意性很大, 不能按照教 师教学的需求, 安排实践。企业培训力量不足; 由于企业 师傅缺少培训技巧, 不能把自己的技术知识完全表达清 楚, 特别是教师让尽快掌握相关技巧的传授方面, 难以达 到培训效果 $[6]$ 。

\section{3. 教师进企业实践活动中问题的对策}

\section{1. 汽车专业相关院校做好专项培训计划, 加强针对性}

汽车专业教师先根据自己知识, 针对自己的薄弱环 节, 提出具体需求, 学校进行汇总, 上交政府相关部门, 像职业院校教师能力发展中心, 再由相关专业人员与企业 沟通, 企业根据自己的情况, 做好相应的准备, 做出预案 和测算，制定方案可以朝两个方向努力。

\subsection{1. 专业品牌内训师计划}

全面接受品牌的专业知识培训, 掌握相关车型维修资 料, 维修手册、维修方法, 维修要点, 维修特点。成为相 关车型专家, 并结合自己教师的授课技巧, 成为宝马内训 师、大众内训师、奥迪内训师、现代内训师、丰田内训师 等等, 实习结束后接受专业厂家考核, 发放类似的证书, 这种模式可以督促教师在实践中, 必须认真学习专业知 识, 也有激情。必须达到能解决实际问题, 只有这样才能 真正的融入企业。如果机制合理的话, 企业可以节省人员, 教师以后长期的担任, 企业的内训师, 定期接受生产厂家 的培训, 然后再给厂家员工培训。

\section{1. 2. 专业模块大师计划}

即把汽车分为发动机模块、底盘模块、自动变速器模 块、电器模块、电控模块、空调模块、附属电器模块、钣 金模块、涂装模块、内饰装调模块、培训结束时接受人社 部门的鉴定中心考核, 发放相关工种的技师证书, 成为领 域专家, 轻松解决相关问题。成立大师工作室, 服务于社 会, 专门解决疑难杂症。

\section{2. 督促企业提供培训方案、落实措施、积累经验}

\subsection{1. 内训师的培训方案}

首先熟悉阶段, 相关车辆结构, 零部件的位置、电路 图的解读、维修手册的认知技巧。其次运用阶段, 老师作 为售后顾问助理 (不影响企业生产) 来解决问题，教师作 为售后顾问助理, 了解汽车故障现象设想的解决方案, 送 到车间后, 技术总监做出处理, 相互比对。达到岗位能力 后, 进行下个阶段学习。即生产汽车厂家的技术培训, 及 时掌握产品更新, 技术变革等专业知识, 真正成为品牌内 训师。

\subsection{2. 专业模块大师的培训方案}

寻找相关企业培训, 后续继续教育要随时更新。专修 企业对自己的专业知识, 肯定是要保留的。因为专项修理 主要是一些厂家甚至 $4 \mathrm{~S}$ 店, 解决不掉的问题送到这里来修, 都是属于疑难杂症类, 来这些地方培训, 其实主要是看别 人如何操作, 如何解决问题的, 企业只会给你一些表象的 东西和培训, 真正掌握到什么程度还是自己悟出来。自己 要收集一些资料, 为维修做准备, 学会解决问题的方法。

改善培训途径, 利用政府出面和汽车生产厂家联系, 去制造厂供货商做售后服务的部门培训像变速器模块, 让 汽车厂家直接联系变速器厂家, 让他们制作详细培训计划 提供资料。来解决维修企业的技术保守问题。 


\section{3. 完善发展培训模式, 协助教师选择}

根据教师的实际情况，选择不同的选派方式，进入企 业实践。培训模式有顶岗挂职模式、调查研究、服务开发 模式、职业研究模式、第二职业模式。顶岗挂职适合对象 是青年教师, 直接派去企业当作企业员工, 像汽车维修与 检测专业的教师，可以从事机修工、售后服务顾问、维修 电工等; 调查研究方式, 比较适合学院系部领导、学科带 头人, 专业带头人, 骨干教师, 进入企业了解企业专业需 要, 建立岗位群, 制定人才培养方案, 制定课程体系。服 务研发模式, 把高水平的教师, 组成专业团队, 给企业员 工培训, 解决企业实际问题, 与企业专家一起研发, 转化 科研成果, 进行技术工艺革新, 教师必须了解行业的前沿 动态, 新技术, 新发展。教师得到提高的同时, 也解决了 企业的实际问题。第二职业模式, 是通过与企业合作, 掌 握新技术后, 在保证教学质量的时候, 去企业兼职, 或者 利用空闲时间开创与专业有关的实体公司等, 像汽车专业 教师可以鼓励去企业应聘技术总监职务, 在学校申请 1-2 年的特殊时期政策。学校也可以鼓励专业教师开办小维修 企业, 让学生一起参与创业, 作为科研项目加以孵化 [7]。

\section{4. 打造互联网+职业院校进企业实践活动平台}

借助网络平台, 给学校教师注册权限, 利用政策吸引 企业参与进来, 打造属于企业自己的网站, 企业可以推广 产品, 打造经营理念, 发布岗位需求, 生产淡旺季, 何时 能接受教师进企业的实践时间, 自己的企业分布网点等, 教师根据自己专业特长, 时间特点, 学校政策等, 实现在 网上与企业预约, 时间可以化整为零, 培训实践可以具体 选择, 像自动变速箱、空调实践的选择, 企业在维修时发 布消息, 教师及时进行联系预约, 快速到现场, 针对性学 习。教师发布学习需求, 企业有机会在维修, 联系教师, 建立互动机制。充分利用互联网优势, 建造专业实习实践 平台。

\section{5. 组织考核, 明确责任}

组织考核: 建立考核方式, 严格执行。服从企业管理, 企业要代管, 制定政策保障。作为企业工作人员要求, 申 请学徒、师傅、甚至技术总监位置。学校企业制定的考核 要求外, 可以结合内训师、模块大师等考核。

明确责任: 活动要取得收效, 健康发展, 发挥自己责 任感, 才能把事情做好, 才能提升自己, 才能发挥自己的 潜力。真正发挥企业实践的作用, 也让自己的吃苦更有价 值 [8]。政府出面建立制度, 学校、企业、教师在实践中 完成自己的任务。在德国等职业教育较好国家, 都有一整 套技术，在企业学校之间，实行联动机制，补偿政策，实 行产学研结合体制。

\section{6 . 立足实践活动本身, 做好延伸工作}

\section{6. 1. 经验交流加强纵向横向学习}

教师去企业参加社会实践活动, 都会有些收获, 例如 汽车专业假设选定内训师这种模式, 有学到了大众系列技 能, 有学到奔驰系列的技术等, 学校组织专题讲座或报告
的形式, 相互交流, 相互学习。按照模块大师法培训, 有 学空调模块, 有学变速器模块等, 也相互交流, 可以事半 功倍。一次学习, 多次得益, 学校可以制定外出学习交流 制度。

\subsection{2. 加强联动机制}

教师进企业实践活动，建立联动机制，教师可以随时 去现场探讨一些疑难问题，给予理论上面的支持，抽象的 问题, 需要故障机理来分析的问题, 发挥教师优势; 但动 手检修, 部件具体地方, 装配技巧不及企业师傅熟练。有 机联动结合, 教师得到实习的机会, 积累了维修案例, 让 自己的课堂更加充实, 同时这个判断问题的思路教给学 生, 就是一堂生动教学课。

\subsection{3. 拓宽形式建立校中厂}

职业院校可以利用专业优势，技术优势、政策优势、 甚至政府力量引厂入校, 建立校中厂, 学校为厂家提供场 地、人员、后勤保障。车企为学校提供教学车辆、技术培 训, 资料支持, 让汽车制造厂家的技术技师来对教师和学 生, 面对面培训, 手把手培训, 真正做到学生毕业后即技 师, 学生毕业后即可进入相关企业, 为企业服务, 而且在 这个领域也变成专家、独挡一面, 加快成长步伐, 教师也 可以兼做厂家的实战型的内训师, 同时极大的提高自己, 能更好的上好课, 打造成真正实践理论一体化的双师教师 $[9]$ 。

\section{4. 进企业实习实践对职业教育效果}

\section{1. 教师专业水平需求与实践活动对教学能力的提升}

以汽车后市场, 维修故障诊断为例。在实习活动中能 否展开深度思考, 根据故障机理, 设计方案, 组织语言和 相关教学程序进行教学。

像一辆索纳塔 8 , 行驶 3 万公里, “发动机开锅” 即发 动机水温过高。在保养期内车辆故障, 可以学习索赔员的 索赔技巧, 工艺流程等。教学中分析温度过高的故障机理, 散热不良, 产热过多。散热不良原因, 无小循环, 冷却液 过少, 散热器表面脏污, 冷却液风扇不转、或转速低、水 洜工作不良等。产热过多是发动机的工作过程有问题, 导 致可燃混合气在气缸内燃烧做的功 (燃烧所释放的能量) 不能完全转化成机械能, 而转化成热能, 造成冷却液温度 过高。混合气的配比, 过浓、过稀, 点火的过早、过晚, 空调等负荷过大等。教师在教学过程中要不断引导启发, 提升学生思考能力, 解决问题能力, 逐步提升教师授课技 巧和实践能力, 产生不同授课效果。

对参与与没有参与实践活动老师授课老师授课情况 调查表, 如表1

表 1 参与实践的老师与没参与实践的老师教学效果比较。

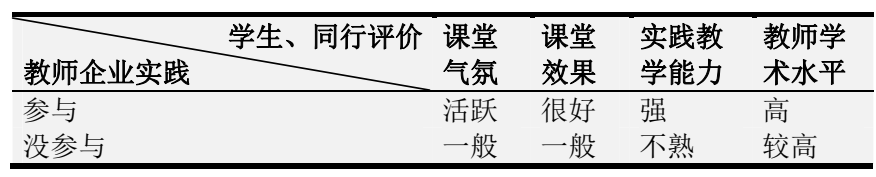




\section{2. 教师进企业实践对学生职业能力的提升}

教师进入企业后, 熟悉汽车专业岗位需求, 企业主要 工作过程, 了解企业工作行为导向, 通过汽车修理厂、汽 车制造厂家、汽车产业衍生企业的实践活动细分企业工作 任务。设置专业领域, 达到国家标准, 企业标准等。岗位 主要是销售, 学习销售知识、技巧、流程, 与客户沟通的
礼仪和方式 [10]; 售后服务, 岗位主要是维修接待, 根据 报修情况分析, 确定维修方案; 去修理车间做维修工人, 或技术总监, 要老师认真领悟, 掌握岗位的技能, 有针对 性的学习, 提升职业能力。上海五菱和合肥职业技术学院 校企合作过程中分成两组, 分别是老师进企业实践和没有 企业实践的教学效果对 240 名学生分成两组各 120 名调查, 如表2。

表2 参与企业实践活动教师教学效果学生状况分析表。

\begin{tabular}{|c|c|c|c|c|c|c|}
\hline 教师企业实践 学生能力 & 适应企业能力 & 领导岗位人数 & 就业流失率 & 一级技术岗位人数 & 问题返修率 & 学生创业情况 \\
\hline 参与 & $80 \%$ & 40 & $5 \%$ & 30 & $0.05 \%$ & $15 \%$ \\
\hline 没参与 & $30 \%$ & 6 & $65 \%$ & 5 & $2 \%$ & $3 \%$ \\
\hline
\end{tabular}

\section{5. 结论}

通过教师企业活动中的问题与对策的分析研究, 从教 学效果看, 无论是把教师培训成内训师, 还是模块大师, 对提升教师教学能力, 达到预期教学效果, 让学生受益。 内训师能针对特定车型, 直接传授厂家的关键技术, 学生 提升也快, 模块大师能精修各种车型的特定知识, 学生专 业很精, 而且设备投入不大, 容易自己创业。根据自己专 业特点, 分析专业情况, 制定专业实践计划, 制定措施和 方案。教师水平提升, 教学能力提高, 有助于学生成长, 建立实践活动机制, 充分发挥与利用国情, 加上教师自己 的努力与思考, 逐步与国际接轨, 利用国外成熟的经验, 与现成的理论, 教师进入企业实践活动提升教师能力。[10] 教师队伍素养就会提高, 学生技能就会提高, 适应社会能 力就会加强, 职业教育就会更好的发展, 更好的适应社会。

\section{致谢}

安徽省教育厅省级质量工程项目：（2016s jjd066） 《合肥职业技术学院安徽风之星投资控股有限责任公司 实践教育基地》的阶段成果之一。

\section{参考文献}

［1］教育部. 关于推进高等职业教育改革创新引领职业教育科 学发展的若干意见 [Z]. 2011-10-20。

［2］杨全利．德国师傅考试制度概述职业教育 [Z]2017-04-05。

[3] 陈家良, 柳军. 高职院校教学质量学生满意度影响因素分 析 [Z]. 2017-3-23。

[4] 许黎英. 职业院校教师企业实践制度改革探析 $[\mathrm{J}]$. 职业教 育基本理论， 2012 (34):55-59。

[5] 韩伟. 职业学校青年教师到企业实践的现状及对策 $[\mathrm{N}]$. 陕 西教育报刊社，2015-03-20。

[6] 职业院校教师到企业实践存在的问题与建议 职教论坛 $[J]$. 戴汉东 石伟平 2015-02 期。

[7] 范方舟. 我国职业院校教师职业能力发展研究 [J]. 职教论 坛. 2010 (7): 70-73。

[8] 罗小秋. 培养高职教师联系行业能力 $[\mathrm{J}]$ 。机械职业教 育. $2004(4)$ : 16-18。

[9] 陈宝生. 加快发展职业教育, 促进产校融合、校企合作. 中 国职业技术教育，2017-3-13。

[10] 姜大源. 职业教育: 培训与教育辨 $[\mathrm{J}]$. 中国职业技术教育, 2008, (7) : 1-1, 24。 